\title{
Evaluating Indonesia's Presumptive Tax Policy on Accountant Professional Services
}

\author{
Neni Susilawati, Raxel Edo Bramasta, Murwendah, Arfah Habib Saragih \\ Department of Fiscal Administration Science, Faculty of Administrative Sciences, Universitas Indonesia, West \\ Java, Indonesia \\ neni.susilawati31@ui.ac.id, raxelbramasta30@gmail.com,murwendah09@ui.ac.id,arfah.habib11@ui.ac.id
}

\begin{abstract}
There is no disagreement about accountants' expertise in bookkeeping. Initially, the assumed tax policy was meant to alleviate bookkeeping requirements for small and medium-sized businesses that were unable to do so. However, why does the accounting profession benefit from not performing bookkeeping if it has specific gross revenue? This issue encourages authors to evaluate Indonesia's presumptive tax regulations for accountants' professional services. The objectives of this research are to ascertain why accountants employ Net Income Calculation Norms to determine their income taxes, to assess presumptive tax policies through the perspective of tax collection principles, and to explore more suitable presumptive tax policies for the accounting profession. This study applies a qualitative method, collecting data through indepth interviews. The findings indicate that the accounting profession's presumptive tax policy fulfills the concept of ease of administration for taxpayers but not the principle of substance over form or revenue productivity. The government should deregulate the policy of Net Income Calculation Norms for Accountant Professional Services so that it maintains consistency with the policy, the objective of providing presumptive taxation to taxpayers with a certain gross sale.
\end{abstract}

Keywords: Presumptive tax, accountant, MSMEs, net income, ease of administration.

\section{Introduction}

Presumptive taxation is a widely used tax policy in Indonesia to encourage individuals and micro, small, and medium-sized businesses (SMEs) to comply with their tax obligations. A large number of SMEs, business owners in Indonesia form the backbone of the country's people's economy, necessitates the government to give alternative means of quickly entering the tax system and exiting the shadow economic zone. Due to the limited ability of individuals and small businesses to perform bookkeeping, the government implemented a presumptive tax policy, an estimation approach for calculating income for tax purposes that eliminates bookkeeping requirements in favor of simply recording gross revenue or turnover. This taxation system has been successful in lowering tax compliance costs by making the tax base more acquainted with the calculation process and in lowering tax collection costs (Wallace, 2002, p. 1). There are two manifestations of Indonesia's presumptive tax policy: Net Income Calculation Norms (NICN) and Final Income Tax for SMEs. Both NICN and Final Income Tax are only intended for business units with a gross turnover of not more than IDR 4.8 billion in one year's tax. This gross income of IDR 4.8 billion is considered the threshold for categorizing a business activity or casual job as an SME. In general, SMEs have limited ability to organize bookkeeping under applicable financial accounting standards. Bookkeeping is the basis needed in determining the payable Income Tax. Therefore, the government provides simplicity and flexibility for this business sector.

By imposing only the obligation to record (no need for bookkeeping) so that there is still a basis for determining Income Tax. This research discusses specifically the NICN, which is intended for both individual Taxpayers and corporate with a gross income not exceeding IDR 4.8 billion with the type of business in the form of professional including professional accountant services. Accountants are certified professionals, who can provide accounting services to other parties who are their clients, including bookkeeping services. Therefore, it creates logical irregularities when the Taxpayers, a profession with expertise in bookkeeping, are encouraged by not doing bookkeeping. In reality, it shows that most accountants, especially private accountants or individuals, prefer to use recording rather than bookkeeping in calculating the amount of payable tax. If designed appropriately, the presumptive tax can alleviate the burden on people. This situation reflects the failure to implement a presumptive tax policy through NICN due to presumptive tax being a stepping stone for Taxpayers to enter the regular tax system (Wallace, 2002, p. 1). The presumptive tax method manifested by recording is only an option if the standard accounting method is unreliable (Thuronyi, 1996, pp. 12-2). This problem encourages the researchers to analyze Indonesia's presumptive tax policies for 
professional accountant services based on basic tax principles and based on the accountants' perspective. In the end, researchers tried to provide an alternative policy for compulsory bookkeeping for accountants.

\section{Literature Review}

Presumptive Tax: In many countries, presumptive tax is used to tax Taxpayers' income, which is difficult to tax with a regular (hard-to-tax) tax administration system. This system calculates the tax base through readily available indicators or other methods, instead of relying on the Taxpayers' self-assessment (Wallace, 2002, p. 1). Therefore, presumptive tax is often seen as a stepping stone towards a regular tax system so that for a limited period, Taxpayers will be subject to this simplified regime. When it has become part of the regular tax system, Taxpayers' income, previously classified as hard-to-tax, can be taxed according to applicable tax laws (Wallace, 2002, p. 1). However, after becoming part of a simplified system, theoretically, the presumptive tax becomes difficult to "disappear" from tax administrators' viewpoint regarding the realm of taxation in the shadow or underground economy. The success of presumptive tax in combating tax avoidance in the last decade is also useful for large Taxpayers. In the end, the presumptive tax becomes a kind of essential requirement in the taxation system, especially in developing countries, which tend to be higher than in developed countries. Taxpayers who can carry out their tax obligations ideally as stipulated in the regular tax system are supposed to benefit both the Taxpayers themselves and the state.

Thuronyi states that presumptive tax is used to show that there is a legal opinion that the income of the Taxpayers is not less than the amount generated from the application of this indirect method $(1996$, p. 1). Referring to Thuronyi's opinion above, the total net income generated from calculating presumptive tax should be the minimum nominal of actual income. From the perspective of the state, when Taxpayers choose to do bookkeeping, the interests of state revenue are safeguarded due to the normative of Income Tax generated from the calculation in bookkeeping is greater than the Income Tax based on calculation results of norms or estimates. On the other hand, the use of bookkeeping in calculating income and Income Tax will necessarily reflect a higher degree of fairness for the Taxpayers. The Income Tax is imposed based on the Taxpayers' ability-to-pay, which is certainly a universal consensus that the principle of justice is a fundamental principle that must be maintained in collecting income tax (Lang, Melz and Kristoffersson, 20099). It was also emphasized in implementing the presumptive tax system. Two things must be ensured; first, small businesses that will develop later into large ones will "pass" and step into the standard tax system. Second, Taxpayers who have stepped into the standard tax system do not "immigrate" to the simplified tax system and pretend to be small business Taxpayers to protect themselves from taxes (Bird \& Wallace, 2003, p. 6).

There are several critical points to remember when designing a presumptive tax to optimize its use, particularly (1) A presumptive tax can be designed to be based on turnover, income indications, or a standard lump-sum assessment (Dube, 2018, p. 2). (2) The presumptive tax design is also rebuttable, as the taxpayer can provide extensive evidence to the tax authorities demonstrating a lower tax burden (Bird \& Wallace, 2003, p. 3). In order to achieve the goal of applying the presumptive tax, the threshold must be revised in a systematic (Bird \& Wallace, 2003, p. 19). Additionally, changing the presumptive tax threshold requires genuine and correct data from representative respondents to acquire data that accurately reflects the unique characteristics of professional services and to develop an appropriate NICN formulation. The prerequisite for this representative respondent is to be able to contribute to the presumptive tax's success (Dube \& Casale, 2017, p. 62) (Dube, 2018, p. 15). (4) Ensure that when the taxpayer's business expands and they are ready to carry out formal bookkeeping and tax duties, they can transition to the official tax system. (5) The taxpayer's use of the presumptive tax must be limited in time. (6) Tax authorities must assist and educate taxpayers who use presumptive tax to prepare them for the transition to the formal tax system (Ogembo, 2018, pp. 39-40).

Net Income Calculation Norms (NICN): NICN is one of the manifestations of the presumptive tax policy in Indonesia. According to Soemitro (1998), the calculation norm is another way, rather than bookkeeping, to determine net income/profit used as the basis for tax imposition. NICN is a fixed percentage for each business type to determine the taxpayer's net profit/income from the total annual turnover value. They are given the freedom to choose whether to use NICN or carry out standard calculations based on bookkeeping. The application of the NICN makes it simple and easy for Taxpayers who have a profession as a professional 
service or professional in calculating taxes on their income. However, on the other hand, the application of the NICN has not provided justice in the tax collection process yet due to the amount of payable tax or the basis of calculating the payable tax if using the NICN is not under the Taxpayer's ability to pay. The amount of payable tax or the basis for the payable tax's imposition is more significant or less than the standard tax calculation based on books by using the NICN.

The advantage of the calculation norm is that it is easy because the Taxpayers do not have to do bookkeeping. On the other hand, the weakness is that the calculation of profit by applying the calculation norm is rough and mostly imprecise (Soemitro, 1998, p. 139). NICN will be successful if it meets these requirements (1) developed by experts who can set the appropriate income figures, (2) updated regularly to reflect the best current economic and financial conditions. (3) In updating, it must consult with industry associations and be announced and open to the public to avoid tax officials' misuse. It also can lead to stimulating Taxpayers who organize bookkeeping of their income, (4) unless the Taxpayers organize bookkeeping, Taxpayers must apply the NICN in calculating their taxable income (Mansury, 1992, p.196).

Principles of Tax Collection: Smith (1776) suggested four principles that must be considered in tax collection, known as four maxims or four canons: equality, certainty, convenience, and efficiency. Equality is the burden received by each tax subject supposed to carry out in a balanced manner following the tax subject's income received or obtained. Certainty is an assurance that must be given to the tax subject with the tax subject's aim to pay the tax clearly and not be delayed or negotiated (not arbitrary). Furthermore, this certainty includes four things: certainty about who the Taxpayers, the certainty of the tax object up to the amount to be paid, certainty regarding when the tax must be paid, and certainty regarding where the tax should be paid. Convenience is a concern in collecting taxes that the government is expected to pay attention to the best or possible time for the Taxpayers. One of the best times in collecting taxes is when Taxpayers receive income such as salaries, bonuses, dividends, royalties, and so on. Meanwhile, efficiency is that tax collection should be carried out economically, where the cost of tax collection does not exceed the tax collected. The tax collection system should be aligned with predetermined principles to create an ideal tax system. Here are some of the tax system's basic principles; (1) the revenue productivity principle related to the government's interests in collecting taxes as a source of state revenue. (2) The government must incorporate the equity or equality principle related to justice in the tax collection process. The tax collected must be under each taxpayer's economic capacity. (3) The ease of administration principle is related to ease of administration.

Which can affect public awareness in carrying out its tax obligations (Mansury, 1996). Zee (in Shome, 1995) stated that the problem of fairness in taxation is generally assessed from two complementary and offsetting matters, namely horizontal equity and vertical equity. Horizontal equity is the imposition of taxes that must be implemented in a general and equitable manner, meaning that all individuals with identical additional economic capacities must be subject to the same taxation. Meanwhile, vertical equity can be accomplished as individuals whose economic circumstances are not the same must be handled differently due to the inequality. According to Mansury (1996), vertical equity can be realized if it meets two conditions: unequal treatments for the unequal and progression. There are several indicators in the ease of administration principle, namely: certainty, stating that there must be certainty from the Taxpayers and the tax authorities regarding the tax subject, tax object, tax base, rates, and how the taxation procedure is. Efficiency can be seen from two sides: the tax authorities and the Taxpayers' side. From the tax authorities' side, the cost of collecting taxes must be lower than the taxes collected. In contrast, from the Taxpayers' side, the cost of carrying out taxation obligations (cost of taxation/compliance cost) should be relatively low. The convenience of Payment, taxes should be collected at the right time (pay as you earn); this is related to the due date of tax payments. Simplicity is easy to implement and straightforward.

\section{Methodology}

This study uses a qualitative method with in-depth interview techniques to understand the reasons for the informants who work as accountants of professional services when they decide to use the recording, to calculate their income tax, not bookkeeping. Interviewees are individuals or SMEs with a gross circulation of not more than IDR 4.8 billion in a year. Besides, we also interview some informants from the Directorate 
General of Taxation and Fiscal Policy in Jakarta, Indonesia. Meanwhile, to analyze the review of taxation principles and alternative policies for applying compulsory bookkeeping for accountants of professional services, the researchers conducted more literature studies. This research was conducted on a small group of individual accountant informants who use the NICN system. The research results will be more comprehensive if carried out on groups of informants who use bookkeeping and represent each province in Indonesia.

\section{Results}

Why Presumptive Tax is Preferable by the Individual Accountants? The recording method (NICN) is the primary option in fulfilling their tax obligations prior to bookkeeping for the majority of professional services accountants with a gross turnover of not more than IDR 4.8 billion per year. Below are several reasons for this:

A. Recording (NICN) is Easier to Do than Bookkeeping: Ease of administration is the first reason for implementing the presumptive tax policy. This convenience takes the form of simplifying the compliance burden of Taxpayers with low gross turnover. It also relates to the appropriate administrative burden for auditing this class of Taxpayers (Thuronyi, 1996, pp. 12-2). The implementation of this policy is contained in the explanation of Article 14 paragraph 1 of the Income Tax Law, which generally states that the NICN policy is applied to assist Taxpayers who have not been able to organize bookkeeping to calculate net income. Taxpayers who use NICN only need to multiply the gross turnover amount by a certain percentage in the NICN related regulations to determine the amount of net income to calculate the amount of payable Income Tax. As illustrated by the schematic table below, assuming that there is no income other than business income:

Table 1: Income Tax Calculation Scheme with Norms

\begin{tabular}{lll}
\hline & Description & Amount \\
\hline A & Gross Income & $\mathrm{xxx}$ \\
$\mathrm{B}$ & Percentage of Net Income (Norms) & $\mathrm{xx} \%$ \\
$\mathrm{C}$ & Net income (a x b) & $\mathrm{xxx}$ \\
$\mathrm{D}$ & Zakat or religious donations & $(\mathrm{xxx})$ \\
$\mathrm{E}$ & Compensation for losses & $(\mathrm{xxx})$ \\
$\mathrm{F}$ & Personal Exemption & $(\mathrm{xxx})$ \\
$\mathrm{G}$ & Taxable income (c-d-e-f) & $\mathrm{xxx}$ \\
$\mathrm{H}$ & Income Tax & $\mathrm{xxx}$ \\
\hline
\end{tabular}

Source: Primary Data (2021)

All informants in this study agreed that using NICN made it easier for them, which was the main reason for their decision to use NICN rather than bookkeeping. When using bookkeeping to determine net income, the Taxpayers must first identify the income that is the object of the Income Tax and then deduct with the allowable expenses to be deducted from the Income Tax provisions. This administrative effort requires more time and a longer process. It can dispute in determining the income and expenses, which has fiscal risks if an audit occurs. The scheme for calculating the Income Tax by bookkeeping is illustrated in the table below:

Table 2: Income Tax Calculation Scheme with Bookkeeping

\begin{tabular}{lll}
\hline & Description & Amount \\
\hline $\mathrm{a}$ & Commercial Gross Income & $\mathrm{xxx}$ \\
$\mathrm{b}$ & Commercial Expenses & $(\mathrm{xxx})$ \\
$\mathrm{c}$ & Commercial Net Income $(\mathrm{a}-\mathrm{b})$ & $\mathrm{xxx}$ \\
$\mathrm{d}$ & Fiscal Correction - Positive & $\mathrm{xxx}$ \\
$\mathrm{e}$ & Fiscal Correction - Negative & $(\mathrm{xxx})$ \\
$\mathrm{f}$ & Fiscal Net Income (c +d - e) & $\mathrm{xxx}$ \\
$\mathrm{g}$ & Zakat or religious donations & $(\mathrm{xxx})$ \\
$\mathrm{h}$ & Compensation for losses & $(\mathrm{xxx})$ \\
$\mathrm{i}$ & Personal Exemption & (xxx) \\
$\mathrm{j}$ & Taxable income (f-g - h- - i) & $\mathrm{xxx}$ \\
\hline
\end{tabular}




$\mathrm{k} \quad$ Income Tax $\quad \mathrm{xxx}$

Source: Primary Data (2021)

According to the accountants who were the informants in this study, NICN is easy to understand so that the accountants can accept it. NICN is more straightforward and less complicated compared to bookkeeping. The use of NICN, which is more concise than bookkeeping, can reduce time and psychological cost; this method prefers to be used by Taxpayers and Tax Authorities. What about direct money costs? It depends on the condition of the actual financial statements. However, Thuronyi theorizes that presumptive tax is the minimum tax, where there is a legal opinion that the taxpayer's income is not less than the amount resulting from the application of this indirect method (Thuronyi, 1996, pp. 12-1). The three dimensions of compliance cost show that the NICN creates a comfort zone for Taxpayers with an inevitable gross turnover (under IDR. 4.8 billion). It is possibly causing Taxpayers to be reluctant to leave this comfort zone to not step into the regular zone. Presumptive tax is declared successful when small businesses grow into big ones; they will "pass" and enter the standard tax system. It must also be ensured that Taxpayers who have entered the standard tax system do not "immigrate" to a simplified tax system-also pretending to be small business Taxpayers to protect themselves from taxes (Bird \& Wallace 122).

B. Opportunities to Legally Pay Lower Income Tax (Tax Avoidance?): The second reason for using the presumptive tax method is combating tax avoidance, which only works if the indicators on which to base estimates are more difficult to hide than those that form the basis for accounting records (accounting) (Thuronyi, 1996, pp. 12-2). Has this goal been achieved with the NICN? Not really. Some informants in this study said that compared to bookkeeping, the amount of Income Tax paid using NICN was lower, although others said it was higher. Besides being able to do bookkeeping, accountants Taxpayers can also compare payable Income Tax generated from the bookkeeping and NICN methods. Fair and economic behavior happens when they prefer a smaller income tax due to lower net income. It can be said that they are also consciously avoiding higher Income Tax, and it is legally valid. It represents one of the loopholes in the Income Tax provisions in Indonesia that must be "patched" immediately because net income should represent the ability to pay (Weston, 1903, p. 183). As stated above, the option to pay taxes lower than what it should be does not reflect the ideal NICN policy. Supposedly, the NICN policy was arranged to encourage Taxpayers to use the normal tax system (bookkeeping) by calculating profit that is greater than expected profit calculated by bookkeeping. This fact enables Taxpayers to take advantage of the NICN policy to carry out tax planning by tax avoidance.

Tax avoidance is carried out to minimize the tax burden by using real alternatives acceptable to the tax authorities. Tax avoidance is "tax affairs" manipulation which still within the framework of existing tax regulations (Suandy, 2008). In the end, this can undoubtedly affect revenue productivity or state tax revenue. An interesting thing was found from research subjects who claim to pay higher Income Tax because they use NICN. Nevertheless, it still does not encourage taxpayers to switch to bookkeeping. The research subjects did not mind paying a higher Income Tax. This tolerance is compensation for the convenience provided by the NICN. However, the researcher thinks that there are two reasons behind the tolerance for Taxpayers who pay this higher Income Tax. First, the relevant Taxpayers have not carried out the proper calculation using the bookkeeping method to be compared with the NICN because Taxpayers are accustomed to recording and implementing NICN. Honesty and tax awareness of Taxpayers are the issues that need to be explored more indepth. Second, the NICN percentage amount does not reflect a close to the actual net income, so the tax burden is still considered relatively light. It becomes one of the weaknesses of NICN that Soemitro stated: the calculation of profit by applying NICN tends to be rough and mostly imprecise (Soemitro, 1998).

\section{Presumptive Tax Policy for Accountants from Tax Principles Perspectives}

A. Substance Over form Principle: If reviewed from the substance over principles form, accountant professional services should be exempted from professional services allowed to use NICN. The initial objective of the NICN policy was to ease the obligation of Taxpayers to do bookkeeping. It is certainly contrary to the condition of the accountant's ability to prepare financial reports. In terms of the equity principle, NICN, which is a form of presumptive tax policy, has been criticized for a long time because it does not reflect the ability to pay in factual that it is considered less in line with the principle of equity. The most 
fulfilled principle by applying NICN is the ease of administration principle, both for Taxpayers and tax authorities. Professional services Taxpayers who apply NICN can easily determine their net income without worrying about getting into many disputes. The amount of payable tax is more specific, and the compliance costs are more efficient. The tax officer is also at ease to supervise or check Taxpayers' tax compliance. However, on the other hand, private accountants who prefer to use recording or NICN can reduce state revenue productivity because they pay lower taxes than bookkeeping. It becomes a long-term problem for state revenues when Taxpayers who use NICN feel comfortable keeping in the zone and do not intend to use bookkeeping and step in the regular tax system.

B. Equity Principle: In the Tax Policy Handbook (Shome, 1995), Zee stated that the problem of fairness in taxation is generally assessed from two complementary and offsetting matters, namely horizontal equity and vertical equity. Horizontal equity means equal treatment for the equals, meaning that the same amount of income is taxed at the same rate. For Taxpayers, including Accountants who choose to use the NICN policy in calculating the amount of payable tax, there is no difference in tax rates with Taxpayers who choose to use bookkeeping, which the tax rates are under Article 17 of the Income Tax Law. Therefore, horizontal equity can be fulfilled in this NICN policy. On the other hand, there is an issue of injustice in determining the amount of net income due to possible differences in the calculation of net income between Taxpayers using NICN policy and Taxpayers' bookkeeping. Even though the Taxpayers are in the same condition (both in the amount of income and expenses incurred), it can affect the amount of payable tax. It can be illustrated as follows: A and B are private accountants or individuals who both have a gross income of IDR 1,000,000,000. Accountants A and B both have a total tax-deductible amounting to IDR 450,000,000. Accountant A chooses to use bookkeeping while Accountant B chooses to use NICN (or recording) in calculating the amount of payable tax. The following is a comparison of the tax calculation payable between Accountant A and Accountant B:

Table 3: Comparison of Income Tax Calculation Scheme

\begin{tabular}{llll}
\hline No. & Description & $\begin{array}{l}\text { Accountant A } \\
\text { (Bookkeeping) }\end{array}$ & $\begin{array}{l}\text { Accountant B } \\
\text { (Norms 50\%) }\end{array}$ \\
\hline $\mathbf{1 .}$ & Gross Income & 1.000 .000 .000 & 1.000 .000 .000 \\
2. & Deductible expenses & $(400.000 .000)$ & - \\
$\mathbf{3 .}$ & Net Income & 600.000 .000 & 500.000 .000 \\
$\mathbf{4 .}$ & Personal Exemption & $(54.000 .000)$ & $(54.000 .000)$ \\
$\mathbf{5 .}$ & Taxable Income & 546.000 .000 & 446.000 .000 \\
$\mathbf{6 .}$ & Income Tax & 107.000 .000 & 81.500 .000 \\
\hline
\end{tabular}

Source: Primary Data (2021)

Based on the illustration above, the Taxpayers Accountant still bears different income tax expenses due to differences in the net income calculation for the same subjective and objective conditions. Another issue of inequity in the NICN policy is that when a Taxpayers choose to use the recording, it means that the taxpayer is considered to be always profitable, even though, in reality, it is in a loss condition. The calculation is only based on gross income without considering costs. Unlike recording, when Taxpayers use bookkeeping, it will adjust the ability to pay Tax. When the Taxpayer is in a profit condition, it will be taxed, whereas if on the contrary, the Taxpayer is not taxed and can compensate the loss to the next tax year if he gets a profit. As an illustration, Accountant A and Accountant B are private accountants or individuals. Both within the last five years had gross income and deductible expenses with the same nominal value as follows:

Table 4: Sample: List of Gross Income \& Deductible Expense in 5 Years

\begin{tabular}{|c|c|c|c|c|c|c|}
\hline No. & Description & 2015 & 2016 & 2017 & 2018 & 2019 \\
\hline 1. & Gross Income & 1.000 .000 .000 & 500.000 .000 & 800.000 .000 & 550.000 .000 & 950.000 .000 \\
\hline 2. & $\begin{array}{l}\text { Deductible } \\
\text { Expenses }\end{array}$ & 400.000 .000 & 550.000 .000 & 500.000 .000 & 600.000 .000 & 450.000 .000 \\
\hline
\end{tabular}

Source: Primary Data (2021)

Accountant A prefers to use bookkeeping, while Accountant B prefers to use NICN. The tax calculation between Accountant A and Accountant B can be illustrated as follows: 
Table 5: Income Tax Calculation for Accountant A (Bookkeeping)

\begin{tabular}{lllllll}
\hline No & Description & $\mathbf{2 0 1 5}$ & $\mathbf{2 0 1 6}$ & $\mathbf{2 0 1 7}$ & $\mathbf{2 0 1 8}$ & $\mathbf{2 0 1 9}$ \\
\hline 1. & Gross Income & 1.000 .000 .000 & 500.000 .000 & 800.000 .000 & 550.000 .000 & 950.000 .000 \\
2. & $\begin{array}{l}\text { Deductible } \\
\text { Expenses }\end{array}$ & 400.000 .000 & 550.000 .000 & 500.000 .000 & 650.000 .000 & 450.000 .000 \\
3. & $\begin{array}{l}\text { Net } \\
\text { Income/Loss }\end{array}$ & 600.000 .000 & $(50.000 .000)$ & 300.000 .000 & $(100.000 .000)$ & 500.000 .000 \\
4. & $\begin{array}{l}\text { Loss } \\
\text { Compensation }\end{array}$ & - & - & $(50.000 .000)$ & - & $(100.000 .000)$ \\
5. & $\begin{array}{l}\text { Personal } \\
\text { Exemption }\end{array}$ & $(54.000 .000)$ & - & $(54.000 .000)$ & - & $(54.000 .000)$ \\
6. & $\begin{array}{l}\text { Taxable } \\
\text { Income }\end{array}$ & 546.000 .000 & - & 196.000 .000 & - & 346.000 .000 \\
7. & Income Tax & $\mathbf{1 0 7 . 0 0 0 . 0 0 0}$ & - & $\mathbf{2 4 . 4 0 0 . 0 0 0}$ & - & $\mathbf{5 6 . 5 0 0 . 0 0 0}$ \\
\hline
\end{tabular}

Table 6: Income Tax Calculation for Accountant B (Norms)

\begin{tabular}{lllllll}
\hline No. & Description & $\mathbf{2 0 1 5}$ & $\mathbf{2 0 1 6}$ & $\mathbf{2 0 1 7}$ & $\mathbf{2 0 1 8}$ & $\mathbf{2 0 1 9}$ \\
\hline 1. & Gross Income & 1.000 .000 .000 & 500.000 .000 & 800.000 .000 & 550.000 .000 & 950.000 .000 \\
2. & Net income & 500.000 .000 & 250.000 .000 & 400.000 .000 & 275.000 .000 & 475.000 .000 \\
& $(50 \%)$ & & & & \\
3. & Personal & $(54.000 .000)$ & $(54.000 .000)$ & $(54.000 .000)$ & $(54.000 .000)$ & $(54.000 .000)$ \\
& Exemption & & & & \\
4. & Taxable Income & 446.000 .000 & 196.000 .000 & 346.000 .000 & 221.000 .000 & 421.000 .000 \\
5. & Income Tax & $\mathbf{8 1 . 5 0 0 . 0 0 0}$ & $\mathbf{2 4 . 4 0 0 . 0 0 0}$ & $\mathbf{5 6 . 5 0 0 . 0 0 0}$ & $\mathbf{2 8 . 1 5 0 . 0 0 0}$ & $\mathbf{7 5 . 2 5 0 . 0 0 0}$ \\
\hline
\end{tabular}

Same conditions between Accountant A and Accountant B, both in the amount of income and the number of expenses incurred, the amount of payable Income Tax is different each year. The difference between the two calculations above is that Accountant B always pays taxes every year even though it suffered a loss in 2016 and 2018. It is because Accountant B uses recording (using NICN) to estimate the calculation based on gross income. Meanwhile, Accountant A, who used bookkeeping, did not pay taxes in 2016 and 2018 because they experienced a loss, and the loss could be compensated for in net income for the following tax year. Related to the vertical equity perspective, NICN still fulfills vertical equity. Vertical equity can be realized if it meets two conditions, namely unequal treatments for the unequal and progression (Mansury, 1996). Taxpayers Accountant who chooses to use NICN or bookkeeping will still calculate the amount of payable Income Tax by using the progressive rates contained in Article 17 of the Income Tax Law. Therefore, the accountants who have higher incomes will pay more taxes than accountants with lower incomes.

C. Ease of Administration Principle: There are four indicators in the ease of administration principle: certainty, convenience, efficiency, and simplicity (Rosdiana and Irianto, 2012). The accountant is obliged to organize bookkeeping in calculating the amount of payable tax. However, the accountant can calculate the payable tax by using the recording (NICN). Meanwhile, accountants who will record must meet specific criteria to clear the boundaries regarding bookkeeping and recording for accountants. The tax collection provisions on the accountant's income have met certainty principles. It must be seen from 2 sides to assess the principle of efficiency; are the tax authority and the Taxpayers' sides. Based on the tax authority side, tax collection is efficient if the cost of collecting taxes by the tax office is less than the amount of tax collected. Then, on the taxpayer's side, the tax collection system is efficient if the costs that must be incurred by the Taxpayers to fulfill their tax obligations can be as minimal as possible. In other words, tax collection can be said efficient if the cost of taxation is low. As quoted from Rosdiana and Irianto (Rosdiana and Irianto, 2012), Cedric Sandford argues that compliance costs consist of fiscal cost, time cost, and psychological cost.

These three things become a reference for researchers to analyze the compliance costs paid by Taxpayers, especially accountants, to meet tax obligations. In terms of fiscal cost, most accountants who choose to use recording can tolerate a fiscal cost that may be more significant than bookkeeping because they prefer the convenience offered when recording. In terms of time cost, calculating the tax payable amount will be faster than using bookkeeping if the accountant uses recording. The recording stages are shorter when compared to 
more complex bookkeeping. Many accountants, especially private accountants or individuals, ultimately prefer to use recording rather than bookkeeping in calculating the amount of payable tax. From the psychological cost side, when choosing to use the recording, the accountant fulfilling his tax obligations is made easier by simplicity. So that the energy expended by the accountant is not too much compared to when doing bookkeeping, it will surely make the accountant's psychological burden become lighter when using the recording with not too much energy expended. The simplicity principle is one of the critical principles in tax collection.

With this principle, a regulation will be more particular, clear, and easily understood by Taxpayers. In calculating the amount of payable tax or fulfilling tax obligations and rights, it must be based on the simplicity principle to increase the Taxpayers' awareness in paying their taxes. The NICN policy fulfills it. Most accountants use the recording (NICN) more than bookkeeping due to the convenience offered by recording, which makes the process of calculating the amount of payable tax becomes more superficial and less complicated. When using the recording, Taxpayers do not need to identify their income type because all types become one total value, resulting in revenue or gross income. Furthermore, by recording, the Taxpayers do not need to identify what burdens are allowed or not allowed in taxes. These expenses are not taken into account in the tax calculation process. In other words, by recording, Taxpayers do not need to make complicated fiscal corrections.

D. Revenue Productivity Principle: Discussing the revenue productivity principle means discussing the government's interests, namely increasing State revenue. The revenue productivity principle is considered the most important principle because it is related to running the government, in which to carry out this requires adequate revenue. However, it hoped that the amount of tax collected would not be too high to hamper the people's economy in its implementation. Most informants in this study who chose to use the recording will pay higher taxes than when they used bookkeeping. On one side, this implies that the accountants who choose to use the NICN policy can increase state revenue productivity. It follows the NICN policy principles, which determine net income above normal net profit when using bookkeeping. However, this is not a severe problem for accountants because they can tolerate it with (NICN) registration convenience. On the other hand, there is a possibility that accountants will pay lower taxes when using recording compared to when using bookkeeping. Therefore, since accountants who use recording pay lower taxes than when they use bookkeeping, there is a potential to reduce state revenue productivity. It can be concluded that there are two possibilities for the use of NICN policies by accountants in influencing revenue productivity, namely increasing or reducing. Therefore, if the government still wants to implement NICN for accountants, it must be ensured that the applied NICN percentage does not allow Taxpayers to pay Income Tax lower than the Income Tax that is generated from bookkeeping. Thus, there must be an adjustment on the NICN percentage amount.

\section{Discussion}

What is the Critic? Regarding the convenience provided by the presumptive tax policy, researchers criticize Thuronyi's thought. Presumptive tax should not be used as a minimum tax, instead of as a maximum tax so that Taxpayers do not linger in their comfort zone because they pay lower taxes than they should. It is enough that this presumptive tax provides advantages in terms of time cost and psychological cost. Taxpayers also have to re-evaluate their direct money costs when the business is growing. In terms of encouraging this movement, it is necessary to apply a time limit (Ogembo, 2018, pp. 39-40) and/or additional prerequisites if Taxpayers can still apply NICN. The government has implemented time limits in using the presumptive tax mechanism through the regulation on the imposition of Income Tax for SMEs. It has other business types other than professional services in the service sector with a gross circulation not exceeding IDR 4.8 billion a year (often referred to as SMEs Final Income Tax. Thus, the government can also consider the NICN regulations for professional services in the service sector. However, other research that is accurate and more specific is needed to be done to determine the percentage of NICN that is close to the general range for the accountant professional service so that the maximum applicable figure can be obtained. As stated by Mansury, one of the conditions for NICN to be successful is that it must be developed by experts who can determine appropriate income figures and must be updated periodically to reflect the best current economic 
and financial conditions. In updating the guidelines, industry associations should be involved in consultations (Mansury, 1992, p. 196).

Balancing the State and Taxpayers Interests: What would be the Better Way? Though most accountants, especially private accountants or individuals, prefer to use the recording, they can do bookkeeping. It is just that the convenience offered by recording causes accountants to prefer to use recording rather than bookkeeping ultimately. However, most accountants are ready to do this if required. This paper is focused on the discussion about the limitations of the Taxpayers' ability to do bookkeeping that accommodated by the presumptive tax policy, which will not be found in the accountant professional services profession. All informants stated that they were ready if required to do bookkeeping. It can be said that the search for a middle ground solution for the two sides of interest (government and Taxpayers) can be shifted further towards the interests of the government. Indeed, it is not easy to oblige accountants to use bookkeeping in the process of calculating the amount of payable tax. The regulations related to the NICN policy are regulated in the Law.

Precisely in Article 14 of the Income Tax Law. If we want to exclude an accountant from the NICN policy, we must also change the Law's provisions. It will be hard to be done because changing the Law requires a long deliberation and process. Also, suppose the NICN policy exception is applied to the accountant. In that case, it will result in inequity in tax collection, and indeed this will violate one of the principles of tax collection, namely tax collection must be fair (Kaho, 2007). It will affect the loss of the accountant's right to use the NICN policy. Except for accountants who cannot use the NICN, it will show a discriminatory tax collection system against a profession or professional services. One thing that might be done is to update the implementing regulations regarding the NICN policy that is currently regulated in PER-17/PJ/2015 due to Taxpayers being able to do tax avoidance that depends on how a country applies its tax regulations (Yuanita et al., 2020, p. 95). One of the critical points that need to be regulated in regulations related to NICN policy is to set a deadline for the use of NICN policies.

As previously explained, the NICN policy includes Taxpayers, which are classified as hard to tax into the taxation system and ultimately encourage them to use bookkeeping. However, in reality, Taxpayers have tended to continuously use the NICN policy without switching to the normal tax system. It occurs because the NICN policy does not regulate the time limit for using the policy, thus creating a separate comfort zone for Taxpayers to continue using the NICN policy. Therefore, it is necessary to update the regulations regarding NICN policies, especially those related to the time limit on using these policies described in the presumptive tax theory. It is not a drastic decision when the government makes regulatory adjustments to exempt the accounting profession from the list of professional services allowed to apply to the NICN. Alternatively, at least provide a maximum time limit (for example, 3-5 years for the transition period) until Taxpayers, along with an accountant of professional services, can apply normal bookkeeping.

\section{Conclusion and Recommendations}

Based on the explanation in the analysis and discussion section, this study can be concluded several things as follows:

a. Fulfillment of the ease of principle is the primary reason why accountants choose NICN over bookkeeping, despite the fact that they are professionals in bookkeeping. Additionally, NICN enables taxpayers to pay less income tax, implying that taxpayers engage in tax avoidance when meeting their tax obligations.

b. NICN for Accountants Taxpayers deserves to be written off based on the substance over form principle. The presumptive tax policy is not adequately targeted if given to a group of Taxpayers who do not have difficulties keeping records as required in the regular tax system.

c. When the NICN for Accountant Taxpayers is to be implemented, modifications to the percentage of net income required to reach the maximum tax that encourages Taxpayers to migrate to the regular tax system must be considered. Additionally, a time limit on the use of NICN should be introduced to ensure that 
taxpayers do not remain in the NICN comfort zone, which does not fairly reflect their ability to pay. These two items may serve as fascinating research subjects for subsequent investigation.

d. The government should make periodic regulatory adjustments to NICN regulations relating to the set net income percentage, business type, and time limit to gradually and progressively encourage taxpayers to enter the normal tax system and eliminate potential tax avoidance taxpayers.

Researchers highly recommend other researchers in the future to complement this research with a more diverse number and types of informants. However, researchers believe that this study's main ideas are important thoughts that the government needs to consider to increase state revenues and the quality of targeted tax policies.

Acknowledgment: This research is funded by the Directorate of Research and Development, Universitas Indonesia under PUTI Grant - Social Humanities $2020 \quad$ (contract number NKB2527/UN2.RST/HKP.05.00/2020).

\section{References}

Bird, R. M. \& Wallace, S. (2003). Is It Really Hard to Tax The Hard-to-Tax? The Context and Role of Presumptive Taxes. International Tax Program, University of Toronto, 1-34.

Dube, G. (2018). The Design and Implementation of Minibus Taxi Presumptive Taxes. Service Industries Journal, no. May. doi:10.1080/02642069.2018.1471138.

Dube, G. and Daniela, C. (2017). Informal Sector Taxes and Equity: Evidence from Presumptive Taxation in Zimbabwe. Development Policy Review.

Kaho, J. R. (2007). Prospek Otonomi Daerah Di Negara Republik Indonesia. Jakarta: PT Grafindo Persada.

Lang, M., Melz, P. \& Kristoffersson, E. (2009). Value Added Tax and Direct Taxation: Similarities and Differences. Amsterdam: IBFD.

Mansury, R. (1992). The Indonesian Income Tax, A Case Study in Tax Reform of A Developing Country. Singapore: Asian-Pacific Tax and Investment Research Centre.

Mansury, R. (1996). Pajak Penghasilan Lanjutan. Ind-Hill Co.

Ogembo, D. (2018). Are Presumptive Taxes a Good Option for Taxing Self-Employed Professionals in Developing Countries? Are Presumptive Taxes a Good Option for Taxing Self-Employed Professionals in Developing Countries? Available at: http://eureka.sbs.ox.ac.uk/7253/1/WP1814.pdf.

Rosdiana, H. \& Irianto. (2012). Pengantar Ilmu Pajak: Kebijakan dan Implementasi di Indonesia. Jakarta: Rajawali Pers.

Shome, P. (1995). Tax Policy Handbook. International Monetary Fund.

Smith, A. (1776). An Inquiry Into the Nature and Causes of the Wealth of Nations.

Soemitro. (1998). Asas Dasar Perpajakan. Jakarta: PT Eresco.

Suandy, E. (2008). Hukum Pajak. Edisi Kedu. Jakarta: Salemba Empat.

Thuronyi, V. (1996). Presumptive taxation, in Tax Law Design and Drafting. International Monetary Fund, (1), 401-433. DOI: $10.1080 / 14631370601008456$.

Wallace, S. (2002). Imputed a Presumptive Taxes: International Experiences and Lessons for Russia, International Studies Program, Andrew Young School of Policy Studies, Georgia State University, International Studies Program Working Paper Series AYSPS, GSU, 2002, 16 pp. Georgia. Available at: https://www.researchgate.net/search.Search.html?type=researcher\&query=presumptive tax.

Weston, S. F. (1903). Principles of Justice in Taxation. New York: Columbia University.

Yuanita, D. W., Devi, N. C., Susilo, Z. A. and Kusharyanti, K. (2020). Foreign investor's interest and tax avoidance: contingency perspectives depending on country's protection level and law systems, Gadjah Mada International Journal of Business, 22(1), 74-98. 